\title{
NOTE ON A CLAY DEPOSIT AT PIENEMPI KUIVAJÄRVI, FINNISH LAPLAND
}

\author{
MATTI SAARNISTO and RAIMO UUSINOKA
}

\begin{abstract}
SAARNISTO, M. and UUSINOKA, R. 1975: Note on a clay deposit at Pienempi Kuivajärvi, Finnish Lapland. Bull. Geol. Soc. Finland 48: $25-31$.

A clay deposit occurring on the eastern side of Pienempi Kuivajärvi, southeast of Ivalo, is described. The clay was accumulated in a proglacial lake. Mineralogical analysis indicates a mineral content not closely similar to those found earlier in Finnish argillaceous sediments and shows a derivation from local granulitic bedrock. Most if not all of the pollen and diatoms are reworked. The pollen spectra include elements which may have originated from Eemian deposits. The diatom flora consists of freshwater small-lake forms.
\end{abstract}

Matti Saarnisto and Raimo Uusinoka, Department of Geology and Palaeontology, University of Helsinki, P.O. Box 115, SF-00170 Helsinki 17, Finland.

\section{Introduction}

In the summer of 1970 one of us (M.S.) became interested in an unusually located clay deposit, situated $15 \mathrm{~km}$ southeast of Ivalo in Finnish Lapland (Fig. 1), between Lake Pienempi Kuivajärvi and the highway leading to Raja-Jooseppi $\left(68^{\circ} 35.5^{\prime} \mathrm{N}\right.$ Lat, $27^{\circ} 52^{\prime}$ E Long; topographical map No. 3832 10, $\mathrm{x}=761444, \mathrm{y}=53564$ ). The southern part of the formation has been excavated for brick production. According to Mr. Kauko Rauhala of Ivalo, who ran the brickyard from the late 40 's until 1956, the main difficulty in production was the unsuitable finegrained material. Pienempi Kuivajärvi is situated somewhat north of the last ice divide and on the lee side of c. $300 \mathrm{~m}$ high Kurupää fell (elev. $457 \mathrm{~m}$ ), in relation to the last ice advance from the southwest. It is in the area of weak glacial erosion which is indicated by a preglacial weathering horizon found in many places in the Saariselkä area not far south of Pienempi Kuivajärvi (Virkkala 1955, Penttilä 1963). Furthermore, the clay deposit at an elevation of $187 \mathrm{~m}$, is almost $40 \mathrm{~m}$ above the highest late-glacial shoreline of the nearby Lake Inari basin (Tanner 1930). The fine material also differs from the late-glacial silty clays found in the Inari basin. These points lead one to conclude preliminarly that the clay is possibly an in situ deposit of interstadial or interglacial origin. However, as will be seen, this assumption did not prove to be correct but the location, mineralogical composition, and pollen and diatom content of the deposit display some interesting features which have 


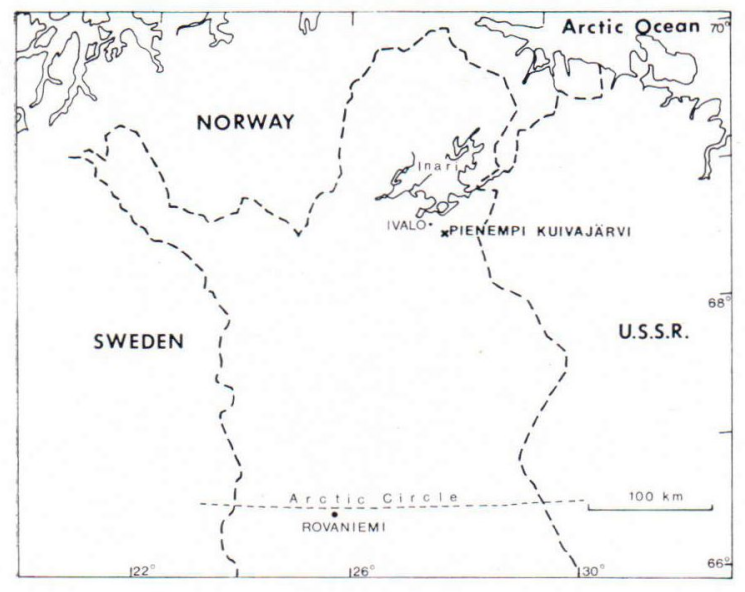

Fig. 1. Index map

not previously been noted in northernmost Finland.

\section{The site and its setting}

The clay deposit forms an elongated north-south orientated ridge, which measures some $200 \times 20$ to $50 \mathrm{~m}$ and extends $2 \mathrm{~m}$ above the level of Pienempi Kuivajärvi. The southern part of the formation has been removed. In Fig. 2 the clay pit and the ridge north of it are shown as the lightcoloured area on the east shore of the lake. The formation continues to the north side of the highway where a pit exposes coarser material, including 80 to 100 varve-like layers composed of sand and silt alternating with clay.

Topography and glacial morphological features in the Pienempi Kuivajärvi area suggest that during the final stage of the deglaciation there was an ice-dammed lake in the Pienempi Kuivajärvi basin. The local ice margin at that time follows a continuous morainic ridge, which belongs to the hummocky moraine area shown on the aerial photograph (Fig. 2). The area of the pro- posed ice-dammed lake is indicated in Fig. 2 together with its drainage directions. Based upon threshold elevations the lake was 15 to $20 \mathrm{~m}$ deep. The clay was most probably deposited in this deep lake which was perhaps partially filled with ice.

\section{Material}

The material was studied in a section $2.5 \mathrm{~m}$ deep on the north side of the pit. The results of the grain-size analyses (Fig. 3) show that the material becomes finer towards the top. Near the surface the clay fraction accounts for $70 \%$ of the grain size distribution which is unusually high when compared with late-glacial fine sediments occurring elsewhere in Finland. Below a clear boundary at about $1.5 \mathrm{~m}$ depth, the material becomes coarser. The total thickness of the deposit is unknown.

The wet clay is dark brown in colour and becomes only slightly lighter when dried. It appears to be homogeneous but in partly dried sediment some fine banding can be seen. The structure of the clay indicates that it accumulated in a calm sedimentary environment. The clay breaks down into irregular pieces along iron-stained surfaces.

For loss-on-ignition analysis the ovendried sample was first kept at $+550^{\circ} \mathrm{C}$ for two hours after which it was weighed. It was then heated to $800^{\circ} \mathrm{C}$ for an hour. Most of the weight loss had already occurred at $550^{\circ} \mathrm{C}$ and most of it can be attributed to the loss of water from clay minerals. This explains the high loss-values in the clay-rich samples.

\section{Mineralogical analysis}

X-ray analysis was carried out on a clayey sample by using CuK $\alpha$-radiation with $\mathrm{Ni}$ filter. The oriented preparate was driven 


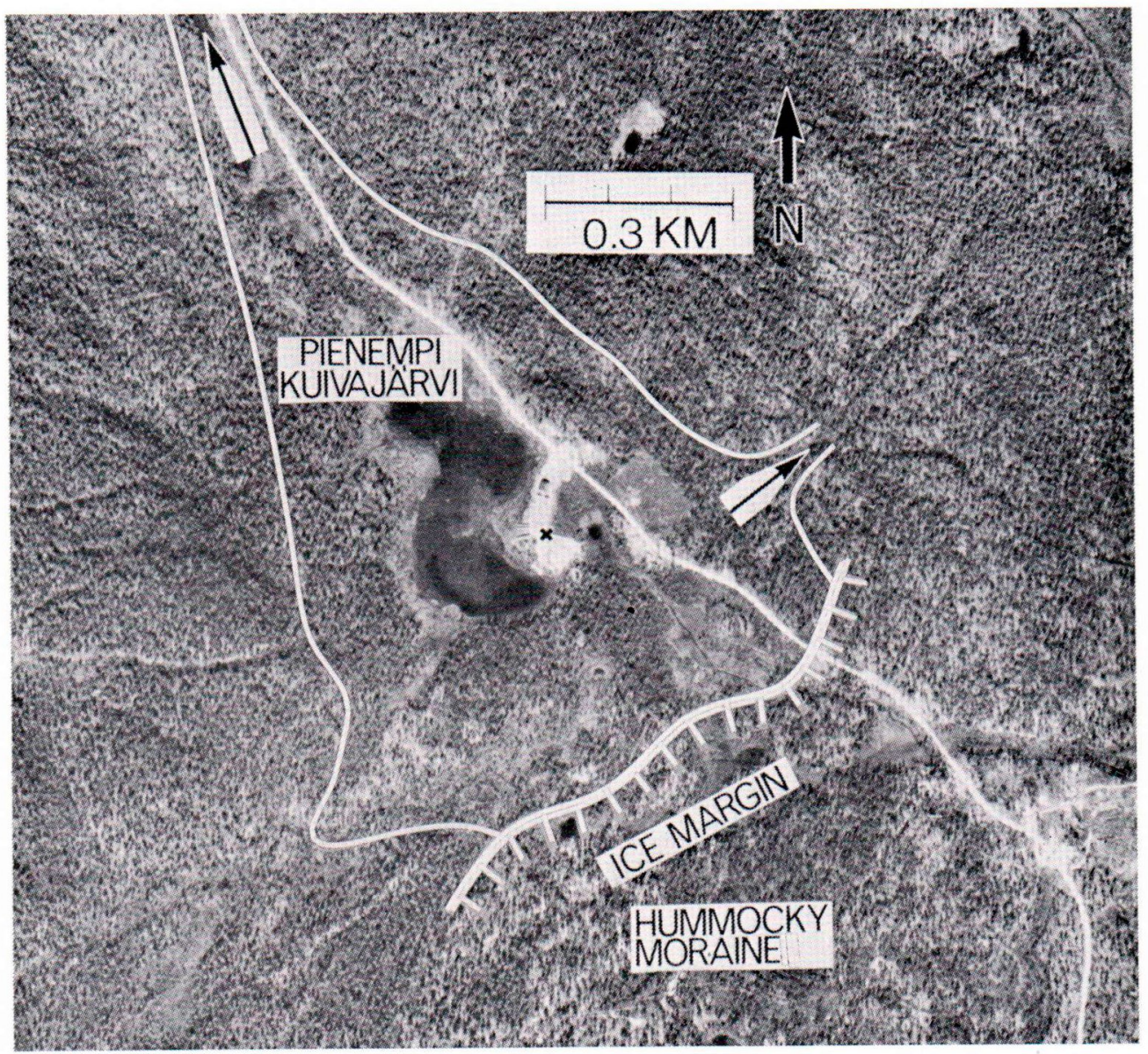

Fig. 2. Aerial photograph showing the proposed ice-dammed lake in the Pienempi Kuivajärvi basin. The sampling locality in the clay deposit is indicated by $x$. By permission of Topografikunta.

both when air-dried, and when heated to $600^{\circ} \mathrm{C}$, at which temperature it was kept for an hour.

The following minerals were identified: biotite, biotite-vermiculite (a mixed-layer mineral, also called hydrobiotite), chlorite, quartz, potash feldspar, plagioclase, and amphibole. On the basis of the reflection intensities, the micas are by far the principal constituents, followed by quartz and chlorite. The (001) reflection of mica was broad and diffuse in the unheated sample, whilst in heated sample the intensity conspicuously grew and the shape of the peak sharpened. This indicates that some layers of vermiculite must be present in the mica as the weathering product of the latter. The reflections at $4.9-5.0 \AA$ and $4.46-4.48 \AA$, typical of illites, were not observed, which indicates that illite is only present in very small quantities if at all. Vermiculite is the weathering product of trioctahedral micas, thus the mica must be biotite containing some mixed-layer mineral biotite-vermiculite. The presence of other trioctahedral micas, at least in notable quantities, is not 
PIENEMPI KUIVAJÄRVI BRICKYARD

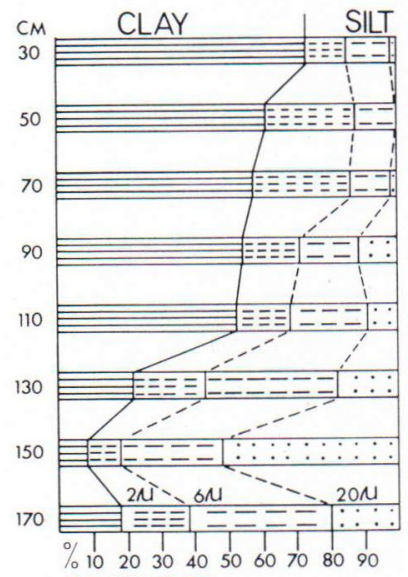

GRAIN SIZE
1971

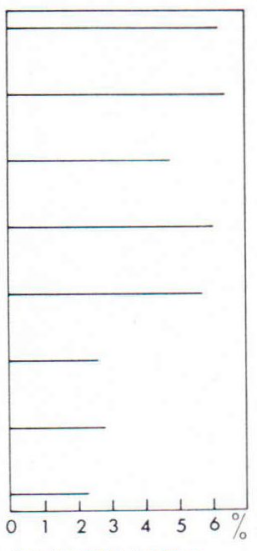

IGNITION LOSS

Fig. 3. Grain size distribution and ignition loss of the Pienempi Kuivajärvi clay deposit.

probable in an area of granulitic bedrock. The (001) reflection of chlorite at $7.1 \AA$, which could also indicate the presence of kaolinite, did not disappear, although the sample was heated at $600^{\circ} \mathrm{C}$ for an hour. Thus, it is highly improbable that kaolinite occurs in the clay.

The mineralogical composition does not indicate a far-advanced weathering process in the formation of the clayey fractions. The weathering products of plagioclase (kaolinite, smectite and/or illite) are absent; only hydrobiotite and chlorite can be regarded as products of weathering, the latter is, however, most probably already formed in the bedrock by hydrothermal processes.

The composition of the Pienempi Kuivajärvi clay does not bear any close resemblance to the argillaceous sediments of southern Finland (cf. Soveri 1956, Gardemeister 1975), which contain illite and vermiculite together with illite-vermiculite, chlorite, and hydrobiotite. Nor is it similar to the few available analyses from the preglacial weathering crust in the Saariselkä area near-

by (see Uusinoka 1975). These contain much illite and/or kaolinite as well as some vermiculite. The weathering products of plagioclase in the preglacial weathering area on the granulitic bedrock of Lapland are illite and kaolinite. No smectite (montmorillonite) has been reported to occur in this area. The material must have been, therefore, derived from glacial debris derived from the granulitic bedrock by the ice-sheet either from the weathering crust or from the fresh rock below. The latter would seem more probable because of the abundance of unweathered minerals present in the clay. However, it must be remembered that the material is reworked and sorted. Thus, the finest fractions (less than about $0.0015 \mathrm{~mm}$ ), most probably containing nearly all the weathering products of plagioclase (kaolinite and illite), may well have been washed away and the coarser fractions consisting mainly of the unweathered material were deposited in the basin.

\section{Pollen stratigraphy}

The deposit is very poor in pollen. Five slides were counted from each level. Pollen grains are most abundant in the silty lower part of the section, but decrease towards the finer topmost sediment. In Somero, southern Finland, most of the pollen in redeposited Eemian clay is found in silty summer layers whereas the finer winter layers contain only a few pollen grains (Donner and Gardemeister 1971). Similarly, the distribution of pollen in the Pienempi Kuivajärvi deposits suggests redeposition. Pollen would thus have been mixed with minerogenic material and sorted during transport and deposition into the silty fraction. The high proportion, up to $30 \%$, of broken and corroded indeterminable pollen also points to redeposition.

Further evidence of redeposition is in the 


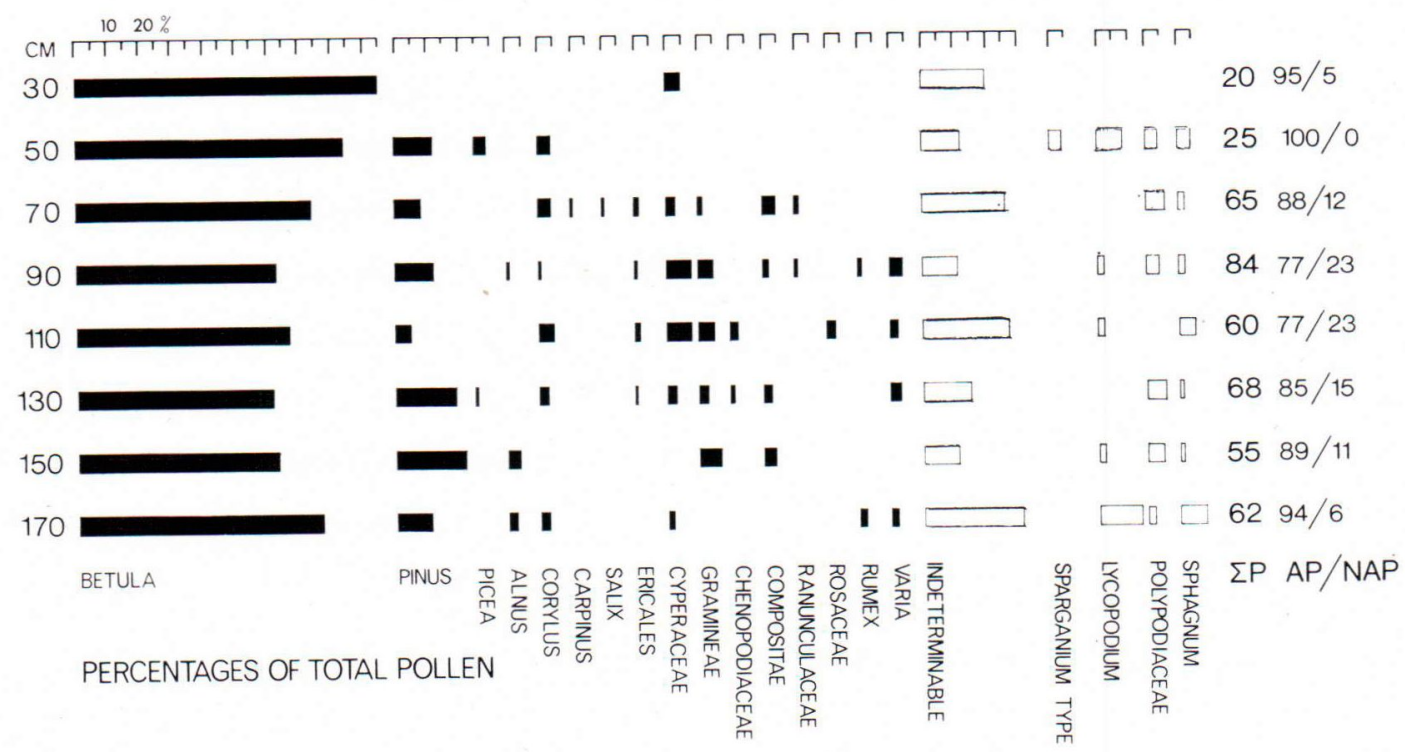

Fig. 4. Pollen diagram of the Pienempi Kuivajärvi clay deposit.

pollen content of the sediment. It has features found not typical of the pollen flora since the last glaciation. During the middle Weichselian interstadial (Peräpohjola or Jämtland), the Pienempi Kuivajärvi area was probably ice-free. This is indicated by an organic horizon found in Vuotso, $70 \mathrm{~km}$ to the south, which is of an equivalent age (Kujansuu 1972). Pollen spectra from this interstadial in Lapland were composed predominantly of Betula (Korpela 1969). The occurrence of Corylus and Carpinus pollen together with that of Picea and Alnus in the Pienempi Kuivajärvi deposit indicates a still greater age. In a separate sample $5 \mathrm{~m}$ distant at $1.3 \mathrm{~m}$ depth four Carpinus pollen grains were found. Korpela (1969) describes the occurrence of Corylus and Carpinus pollen in till antedating the middle Weichselian Peräpohjola interstadial deposits in southern Lapland. Similarly the in situ organic deposits at Sokli, southern Lapland, almost certainly of Eemian age, contain Corylus pollen (Ilvonen 1972). They also have high quantities of Picea pollen which is however rare in Pienempi Kuivajärvi. At present Sokli is situated within the spruce forest zone whereas Pienempi Kuivajärvi lies immediately north of the spruce tree limit.

The pollen of the interglacial organic deposits in Leveäniemi, Swedish Lapland lead Robertsson (1971, see also Lundqvist 1971) to conclude that Corylus was growing $800 \mathrm{~km}$ north of its present limit during the Eemian. Similarly, in the Kola Peninsula, Corylus pollen is typical in the Eemian deposits (Armand et al. 1969, according to Lundqvist 1971).

In conclusion, the pollen content of the Pienempi Kuivajärvi deposits suggests an interglacial, perhaps Eemian age, for some of the pollen, mixed with interstadial and primary early Holocene pollen indicated by high Betula values.

\section{Diatoms}

The diatoms are listed in Table 1 . The sedimentation of diatoms shows similar fea- 
Table 1. List of diatoms of the Pienempi Kuivajärvi clay deposit.

Depths $30 \mathrm{~cm}$ and $50 \mathrm{~cm}$ : none found.

Depth $70 \mathrm{~cm}$ : Melosira frag. 1.

Depth $90 \mathrm{~cm}$ : Amphora ovalis 2, Cyclotella comta 1, Cymatopleura solea 1, Epithemia zebra var. saxonica 1, Fragilaria construens 3,Gyrosigma Kütsingii 1, Navicula radiosa 4, Navicula sp. 1, Pinnularia gibba 4, Pinnularia mesolepta 1, Pinnularia sp. 1, Rhobalodia gibba 11, Stauroneis phoenicenteron 2, Stauroneis frag. 1, Surirella biseriata 7, Surirella frag. 3, Synedra affinis var. obtusa 1. Sum total 45.

Depth $110 \mathrm{~cm}$ : Pinnularia frag. 1.

Depth $130 \mathrm{~cm}$ : Amphora ovalis 1, Comphonema acuminatum var. coronata 4, Cymbella lacustris 1, Cymbella ventricosa 1, Eunotia pectinalis 1, Epithemia sorex var. gracilis 2, Epithemia zebra var. porcellus 1, Epithemia sp. 1, Navicula cuspidata var ambiqua 1,Navicula pupula var. rectangularis 1 , Navicula radiosa 2, Navicula frag. 1, Navicula sp. 1, Nitzschia acuta 1, Pinnularia mesolepta 2, Pinnularia frag. 2, Surirella biseriata var. bifrons 5, Surirella robusta var. splendida 1, Surirella frag. 6, Stauroneis anceps fo linearis 2. Sum total 37.

Depth $150 \mathrm{~cm}$ : Eunotia frag. 1, Pinnularia maior 1, Pinnularia frag. 2, Surirella biseriata 1.

Depth $170 \mathrm{~cm}$ : Cymbella parva 1, Cymbella sp. 1, Fragilaria sp. 1.

tures to that of the pollen. They are most abundant in the coarser silty sediment and absent in the fine clay fraction. This may be partially due to the decanting and sieving method used during the preparation, but is more likely, related to the deposition of reworked material. The diatoms are freshwater small-lake forms which on the basis of their distribution in the deposit, perhaps did not live in a proglacial basin. More probably they were derived from older lake sediments. It should be pointed out, however, that Melosira distans, Navicula radiosa, Rhobalodia gibba and Cymbella ventricosa are among those diatoms which Mölder (1951) found in recent ice-marginal lakes in Norway and Iceland.

\section{Summary}

The glacial morphology and topography near Pienempi Kuivajärvi indicates that the clay formation on its east shore was most probably deposited in an ice-dammed lake, during the final retreat phases of the Weichselian glaciation. The deglaciation of this part of Lapland took place during early Holocene time (Saarnisto 1973).

Mineralogical analysis indicates a mineral content not closely similar to those found earlier in Finnish argillaceous sediments. The principal constituents are micas, followed by quartz and chlorite. They indicate the origin of mineral matter from weathered and/or unweathered horizon of the local granulitic bedrock.

The sedimentation of pollen and diatoms with the silt fraction points to a redeposited origin. Corylus and Carpinus pollen found in the Pienempi Kuivajärvi deposit suggests an Eemian age for some of the pollen, together with interstadial and primary, early Holocene pollen. The diatoms originate from redeposited freshwater sediments.

Thus the Pienempi Kuivajärvi clay deposits seem to consist of materials of different ages, which were mixed during the last glaciation. These were then sorted during transport and sedimentation in the calm waters of the ice-dammed lake which was formed in the Pienempi Kuivajärvi basin during the final stages of deglaciation.

Acknowledgements - The authors wish to thank Dr. R. Tynni for invaluable discussions regarding the microfossils, and Dr. P. Gibbard for checking the English of the manuscript. 


\section{REFERENCES}

Armand, A. D., Armand, N. N., Grave, M. K., Evzerov, V. Ja. and Lebedeva, R. M. (1969) Generalized scheme of Quaternary (Anthropogen) Deposits of the Kola Peninsula in the light of the new data (in Russian). Akad. Nauk USSR Main Problems of Geomorphology and Anthropogen Stratigraphy of the Kola Peninsula. Leningrad.

Donner, J. J. and Gardemeister, R. (1971) Redeposited Eemian marine clay in Somero, southwestern Finland. Appendix by Risto Tynni. Bull. Geol. Soc. Finland 43: $73-88$.

Gardemeister, R. (1975) On engineering-geological properties of fine-grained sediments in Finland. Technical Research Centre of Finland. Building Technology and Community Development. Publ. 9. 91 p.

Ilvonen, E. (1973) Eem-kerrostuma Savukosken Soklilla. Summary: An Eem-Interglacial deposit at Sokli in Savukoski, Finnish Lapland. Geologi 25 (8): $80-84$.

Korpela, K. (1969) Die Weichsel-Eiszeit und ihr Interstadial in Peräpohjola (nördliches Nordfinnland) im Licht von submoränen Sedimenten. Ann. Acad. Sci. Fenn. A. III. 99. 108.

Kujansuu, R. (1972) Interstadiaalikerrostuma Vuotsossa. Summary: Interstadial deposit at Vuotso, Finnish Lapland. Geologi 24 (5-6): 53-57.

Lundqvist, J. (1971) The interglacial deposit at the Leveäniemi mine, Svappavaara, Swedish Lapland. SGU C 658.

Mölder, K. (1951) Die Diatomeenflora einiger
Eisrandstandorte in Norwegen und Island. Arch. Soc. Zool. Bot. Fennicae »Vanamo» 5 (2): $126-137$.

Penttilä, S. (1963) The deglaciation of the Laanila area, Finnish Lapland. Bull. Comm. Géol. Finlande 203. $71 \mathrm{p}$.

Robertsson, A-M. (1971) Pollenanalytical investigation of the Leveäniemi sediments. Appendix 4 in J. Lundqvist: The interglacial deposit at the Leveäniemi mine, Svappavaara, Swedish Lapland. SGU. Ser. C. No. 658: 82-103.

Saarnisto, M. (1973) Contributions to the lateQuaternary history of the Lutto River valley, Finnish Lapland. Soc. Sci. Fenn., Comm. Phys. Math. 43: 11-20.

Soveri, U. (1956) The mineralogical composition of argillaceous sediments of Finland. Ann. Acad. Sci. Fenn. A III 48.

Tanner, V. (1930) Studier över kvartärsystemet i Fennoskandias nordliga delar IV. Résumé: Etudes sur le systéme quaternaire dans les parties septentrionales de la Fennoscandie IV. Fennia 53 (1).

Uusinoka, R. (1975) A study of the composition of rock-gouge in fractures of Finnish Precambrian bedrock. Soc. Sci. Fenn., Comm. Phys.-Math. 45 (1). $101 \mathrm{p}$.

Virkkala, K. (1955) On glaciofluvial erosion and accumulation in Tankavaara area, Finnish Lapland. Acta Geogr. 14: 393-412.

Manuscript received, June 9, 1975. 